\title{
ORGANISATIONAL INERTIA: CONTRASTING RESULTS IN AUSTRALIA AND SOUTH AFRICA
}

\author{
GERT ROODT \\ CARLI KINNEAR \\ Department of Human Resource Management, \\ Rand Afrikaans University \\ RONEL ERWEE \\ University of Southern Queensland, \\ Toowoomba, Australia
}

\begin{abstract}
This study investigates the similarities of scores on the Organisational Inertia Survey in executive samples in Australia and South Africa. The study builds on previous research on the metric qualities of the Organisational Inertia Survey and problems associated with assuming cross-cultural equivalence of measuring instruments. The sample for this study included a SA sample of 617 executives from different companies and 340 Australian executives from the Australian Institute of Management who participated in an Australian survey. The results show that a twofactor structure with a high internal consistency was extracted in the combined sample. The conclusion from further analyses is that significant differences exist in the obtained Organisational Inertia scores between Australian and South African examples and between male and female respondents.
\end{abstract}

\section{OPSOMMING}

Hierdie studie ondersoek die ooreenkomste tussen tellings van Australiese en Suid-Afrikaanse bestuurders op die Organisasietraagheidvraelys. Die studie bou op vorige navorsing rakende die metriese eienskappe van die organisasietraagheidvraelys en probleme wat met die aanvaarding van tussen-kulturele ekwivalensie van meetinstrumente geassosieer word. Die steekproef vir hierdie studie het 617 Suid-Afrikaanse bestuurders uit verskillende maatskappye ingesluit en 340 Australiese bestuurders van die Australiese Bestuursinstituut wat aan die ondersoek deelgeneem het. Die resultate dui op 'n tweefaktor struktuur met 'n hoë interne betroubaarheid wat uit die gekombineerde steekproef onttrek is. Die gevolgtrekkings uit verdere ontledings is dat daar beduidende verskille bestaan in organisasietraagheidtellings tussen Australiese en Suid-Afrikaanse bestuurders en tussen manlike en vroulike respondente.

\section{Organisational inertia}

Research on organisational change is undergoing a metamorphosis (Pettigrew, Woodman \& Cameron, 2001). Generalisations about organisational change models are difficult to uphold across institutional, international or cultural borders. These authors include the investigation of international and cross-cultural comparisons in research on organisational change as one of six interconnected analytical issues that need to emerge in future research. Preliminary findings of research conducted by Pettigrew and associates about new organisational forms indicated a process of incremental rather than a radical pattern of innovation in organisations.

The study reported in this article is part of a series to investigate the portability of measuring instruments of organisational culture and inertia in two societies, South Africa and Australia (Erwee, Lynch, Millett, Smith \& Roodt, 2001; Kinnear \& Roodt, 1998a; Kinnear \& Roodt, 1998b; Roodt, Kinnear, Erwee, Smith, Lynch \& Millett, 2001).

Organisational inertia can be described as the resistance of an organisation to make transitions and an organisation's inability to quickly and effectively react to change (Kinnear \& Roodt, 1998a, p. 44). (See figure 1).

A paradox in organisational inertia is that there is simultaneously a tendency for change resistant forces to reinforce existing management practices while generating a force or momentum to maintain the status quo. This paradox is aptly illustrated in Figure 1. The conceptual foundations for inertia originated with American models such as Lewin's force field analysis, Burke and Litwin as well as Burke's systems model of transformational and transactional change (Erwee \& Pantke, 1997; Kinnear \& Roodt, 1998a). The Burke - Litwin change model (see Figure 2) illustrates the transformational and the transactional dimensions of change.

Requests for copies should be addressed to: G Roodt, Department of Human Resource Management, RAU University, PO Box 524, Auckland Park, 2006

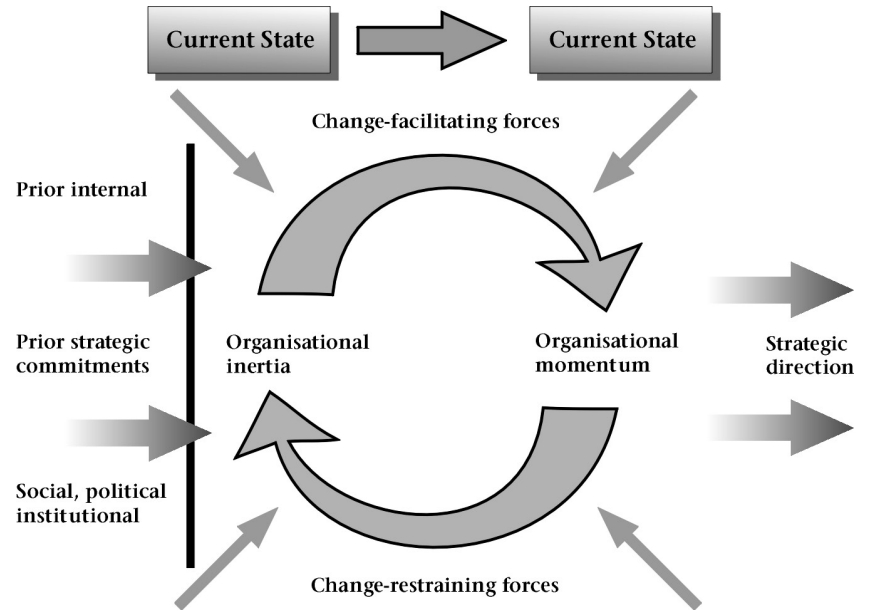

Figure 1: Adapted inertia model from Connor and Lake (Adapted from Connor \& Lake, 1988, p. 69)

Kinnear and Roodt (1998a) adapted the Burke-Litwin model (Burke, 1992) to provide a more holistic view of organisational inertia to include specific dimensions that focus only on aspects that actively contribute to inertia in organisational change efforts. Examples are aspects such as change leadership, workunit climate as inertia factor, change related systems, task requirements and individual skills, abilities, needs and values applicable to change. The authors point out that difficulties in transformation efforts in companies often relate to failures of adequately coping with psychosocial dynamics during the change phases. This confirms the original statements by Burke that the transformational variables are inherently more powerful influences on the organisation's orientation to change. Therefore structural elements, transformational variables such as leadership on the acceptance of change, resistance from 


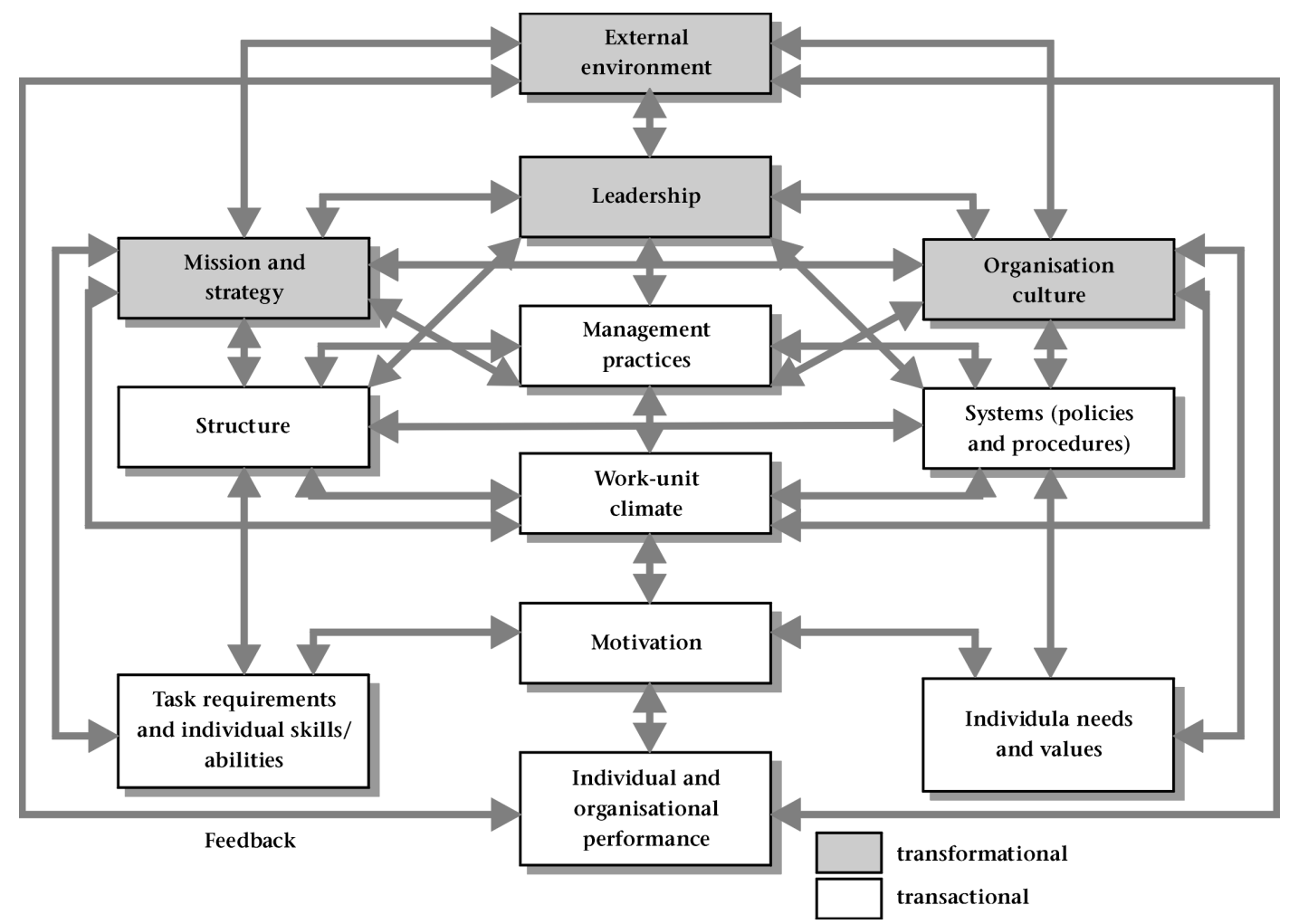

Figure 2: Adapted Burke-Litwin change model (Adapted from Burke, 1992, p. 128)

operational levels, perceptions of betrayal of psychological contract and prevailing culture in organisations are all variables that need to be taken into account when designing measuring instruments to capture a multidimensional phenomenon. A consistent finding in cross-cultural research on organisational change is that successful system wide change requires the use of multiple change levers many of which involve various work processes (Pettigrew, et al., 2001).

\section{Cross cultural research}

There are specific challenges associated with cross-cultural research in the field of business. Differences between nations' cultures are associated with differences in the organisational culture, management theory and practices occurring at a local level. Research during the 1990's confirms the impact of national culture on managerial behaviour (Adler, 1997) as well as the assumptions that companies make when they send female executives to foreign locations (Adler \& Izraeli, 1994). Booysen (1999) pointed out that future leadership needs will be different to the current male dominated styles in South Africa and that this future profile overlaps to a large extent with the female leadership profile. Patrickson and O'Brien (2001) focused on the diversity of workforces of countries in Asia and the Pacific region. They have analysed a range of macro level factors that impacted on workforce diversity in a society and compared and contrasted twelve countries on how diversity is managed, especially by multinational corporations.

The debate about whether multinational corporations should opt for consistent management practices across national borders or should they employ a culturally specific management techniques still rages. Recent research suggests that two management practices namely empowerment and continuous improvement may be particularly sensitive to cultural fit (Marchese, 2001). The arguments for this concept is linked to national cultural dimensions such as individualismcollectivism and power distance (see Hofstede, 1993; Trompenaars, 1993). The results indicate that the fit between empowerment and power distance is more pronounced in low power distance cultures.
The extent of the differences between the South African and Australian national cultures and management practices remain something of an unknown. Some similarities in terms of national culture can however be postulated using Hofstede's (1993) framework and research findings. Both countries have low scores on power distance (Aus 36, RSA 49). Australia is more individualistic than South Africa (Aus 90, RSA 56). Both have similar masculinity (Aus 61; RSA 63) and uncertainty avoidance scores (Aus 51; RSA 49). These findings should however be interpreted with caution, as research by Kruger and Roodt (2002) indicated that Hofstede's VSM-94 is suspect when applied in a cross-cultural setting.

The Ubuntu management philosophy incorporates South African indigenous world-views as well as western management concepts (Mangaliso \& Nkomo, 2001). Ubuntu played a significant role in the transformation of Eskom, a state-owned electrical utility in partnership with American and South African firms. The African concept of humaneness and spirituality are based on values of caring and compassion and these concepts and values influence management practices. Research by Booysen (2001) reiterated the differences between Black and White management approaches or what is also known as Eurocentric and Afrocentric management approaches. However, Mangaliso (2001) cautioned that several customs carried out in the name of ubuntu are based on erroneous superstitions leading to practices that could be oppressive and sexist or stifle individual aspirations. As culture is not static, differences are becoming more pronounced between the behaviours of urban and rural people, younger and older generations or university educated and semiliterate people.

It could also be postulated that Australian management is similarly a reflection of Australia's unique culture and circumstances. For example Australia's approach to balancing work - recreation is another unique aspect of Australian business as Australians may have a better balance between work and recreation than their US colleagues. Australians seem to work so that they can play. '(Australians)... realise that merely putting in long hours isn't what's important-it's the output you achieve not the input required.' (Blount, Joss \& Mair, 1999, pp. 202-203). 
Cross cultural equivalence of surveys

As the socio-economic, legal and political contexts differ between societies, researchers cannot assume that models and surveys piloted in South Africa have cross-cultural equivalence in an Australian context (Adler, 1997). When testing a model developed in a particular context in another country, issues such as a lack of semantic equivalence across languages in a survey, a lack of conceptual equivalence of models across cultures and normative differences are relevant in interpreting results (Behling \& McFillen, 1997; Du Babcock \& Babcock, 1997). The implication for cross-national research, as pointed out by Kruger \& Roodt, (2002) is that questionnaires in the English language that are reliable in one country may contain concepts or phrases that are not interpreted consistently in another English speaking country. South African organisational cultures and structures are based on western management philosophies, but as the country is undergoing rapid change one might expect that these cultures will change in the near future (Mangaliso \& Nkomo, 2001). However, the reality is that a learning orientation must prevail in organisational cultures to survive and grow competitively in the African as well as global contexts (Mangaliso, 2001).

These perspectives about the embeddedness of research and business practices in national cultures must influence the development of instruments such as the Organisational Inertia Survey outside its culture of origin.

The research issue that is pursued in this follow-up study is therefore whether there are significant differences between Organisational Inertia scores of Australian and South African managers on the OIS.

\section{METHOD}

\section{The sample}

The researchers used the original samples obtained during the previous South African (Kinnear \& Roodt, 1998a; Kinnear \& Roodt, 1998b) and Australian studies (Roodt, et al., 2001). In both studies convenience sampling imply that the findings cannot be generalised to other managerial samples in different parts of the two countries. The biographical characteristics of the sample are described in Table 1.

TABLE 1

BIOgRaphical Characteristics of THE Australian and South African Samples

\begin{tabular}{|c|c|c|c|c|c|}
\hline \multicolumn{6}{|l|}{ GENDER } \\
\hline \multicolumn{2}{|l|}{ Country } & \multicolumn{2}{|l|}{ RSA } & AUSTRALIA & TOTAL \\
\hline Male & & \multicolumn{2}{|l|}{400} & 248 & 648 \\
\hline Female & & \multicolumn{2}{|l|}{216} & 91 & 307 \\
\hline TOTAL & & \multicolumn{2}{|l|}{616} & 339 & 955 \\
\hline \multicolumn{6}{|c|}{ HIGHEST ACADEMIC QUALIFICATION } \\
\hline Country & & \multicolumn{2}{|l|}{ RSA } & AUSTRALIA & TOTAL \\
\hline Lower than 12 years & & \multicolumn{2}{|l|}{31} & 14 & 45 \\
\hline 12 years & & \multicolumn{2}{|l|}{209} & 14 & 223 \\
\hline 12 years with diploma & & \multicolumn{2}{|l|}{200} & 58 & 258 \\
\hline Undergrad degree & & \multicolumn{2}{|l|}{87} & 106 & 193 \\
\hline Post grad degree & & \multicolumn{2}{|l|}{66} & 148 & 214 \\
\hline TOTAL & & \multicolumn{2}{|l|}{593} & 340 & 933 \\
\hline \multicolumn{6}{|l|}{ AGE } \\
\hline Country & $\mathrm{N}$ & & Mean & SD & SE \\
\hline RSA & 615 & & 39,26 & 10,10 & 0,41 \\
\hline AUSTRALIA & 339 & & 43,49 & 8,21 & 0,45 \\
\hline TOTAL & 954 & & & & \\
\hline
\end{tabular}

Varying totals are attributed to missing values
It appears from Table 1 that the majority of the respondents were male with the Australian sample including more males (73\%) than the South African sample (65\%). The South African sample included more managers with Year 12 schooling or Year 12 and a diploma (69\%) than these categories in the Australian sample (21\%). The mean age for the Australian sample (44 years) was higher than that of the South African sample (39 years).

\section{Measuring instrument}

The Organisational Inertia Survey (OIS), was constructed by Kinnear \& Roodt (1998a) by categorising and synergising the overlapping dimensions of organisational inertia, based on the adapted Burke-Litwin model. (Refer to Figure 2 for more detail on the transformational and transactional dimensions of the model). One hundred and nine items with seven-point Likerttype response scales were generated. A South African convenience sample of managers returned 617 questionnaires and first and second level factor analyses followed by iterative item analyses were conducted. The first scale Organisational Inertia consisted of 94 items with the majority of item-test correlations between 0,5 and 0,7 , item reliability indices that varied between 0,34 and 1,00 and an internal consistency (Cronbach Alpha) of 0,981 . The second scale consisted of 15 items with item-test correlations between 0,32 and 0,71 , item reliability indices varied between 0,47 and 1,00 and an internal consistency of 0,88 was obtained. This scale was labelled External change forces, change strategy and imposed personal demands. The authors concluded that organisational inertia could be mitigated through improved people-management practices during change initiatives. They recommend the testing of the instrument in culturally diverse environments.

The OIS was subsequently tested on convenience samples of the Australian Institute of Managers and mature MBA student samples in Australia, yielding 340 respondents (Roodt, et al., 2001). The results of the factor analyses and the item analyses indicate that the OIS is equally appropriate in the Australian context. The factor analyses yielded a single scale with a high internal consistency, which was slightly higher than the 0,981 of the South African sample. Only a single factor was extracted, in comparison with the two factors in the South African sample. The theoretical dimensions were replicated successfully in the Australian sample and all of them had high factor loadings. The dimension with the lowest factor load is similar to the second factor in the South African sample namely the "external forces for change". It seems that the Australian sample perceived this dimension as an inertia-contributing factor, as opposed to the South African sample.

"The internal consistency, however, hints that the construct 'organisational inertia' was measured effectively in the Australian context with a minimum amount of error variance" (Roodt et al., 2001, p.61). It appears that the OIS can be used successfully in Australia and that it is not affected by a "different" culture. This can probably be ascribed to the fact that South Africa and Australia have a similar or shared "western" business culture. Items that were omitted during the iterative item-analyses overlap largely with the items included in the second factor of the SA sample or the items that were omitted in the item analysis procedure. It seems as if the items finally included in the Australian and South African samples are largely overlapping.

\section{Statistical analysis}

Permission to use the OIS in Australia was conditional on the data-analysis and factor analyses being done by the research team members in South Africa. The Statistical Consultation Service of the Rand Afrikaans University conducted the statistical analyses. For the factor analyses, a procedure suggested by Schepers (1992) was used. An iterative item analysis procedure was conducted by using the NP50 program of the National Institute of Personnel Research (NIPR). 


\section{RESULTS}

The first level factor analysis (Schepers, 1992)

The first level factor analysis was conducted on the complete dataset of the combined South African and Australian samples with no missing values $(\mathrm{N}=724)$. Ninety-seven items were intercorrelated and a Kaiser-Meyer-Olkin Measure of Sampling Adequacy (MSA) of 0,979 was obtained. This indicated that the matrix was suitable for factor analysis. Eigenvalues were consequently calculated.

Seventeen factors were postulated based on Kaiser's (1961) criterion of eigenvalues greater than unity. Three factors had no significant item loadings so that fourteen factors remained.

The matrix was rotated to a simplified structure by means of a Varimax rotation and Kaiser normalization.

\section{Second level factor-analyses (Schepers, 1992)}

The complete dataset of the combined SA and Australian samples $(\mathrm{N}=942)$ was used for this analysis. The sub-scores on the fourteen factors were intercorrelated. An anti image correlation delivered measures of sampling adequacy with most greater than 0,9 and which were deemed acceptable for factor analysis. Eigenvalues were again calculated.

Two factors were postulated based on eigenvalues greater than unity (Kaiser, 1961). The matrix was rotated to a simplified structure with a Direct-Oblimin rotation and Kaiser normalization (see pattern matrix in Table 2).

TABLE 2

Pattern Matrix

\begin{tabular}{lcc}
\hline FACTOR & 1 & 2 \\
\hline SFS 2 & 0,803 & $-0,187$ \\
SFS 3 & 0,789 & $-0,134$ \\
SFS 7 & 0,779 & $-0,219$ \\
SFS 9 & 0,748 & $-0,126$ \\
SFS 5 & 0,733 & $-0,136$ \\
SFS 1 & 0,726 & $-0,383$ \\
SFS 4 & 0,692 & \\
SFS 10 & 0,629 & 0,218 \\
SFS 6 & 0,625 & \\
SFS 13 & 0,559 & 0,115 \\
SFS 8 & 0,499 & 0,161 \\
SFS 14 & 0,483 & $-0,463$ \\
SFS 11 & 0,322 & 0,353 \\
SFS 12 & & \\
\hline
\end{tabular}

An item-analysis on Scale 1 with items A1, C7, H2, H3, I1 12, I3 and I4 omitted, delivered an acceptable coefficient Alpha of 0,9840 . The items included in this scale, all refer to organisational inertia.
An item-analysis on Scale 2 with only 5 items provides a less acceptable coefficient Alpha of 0,6484. The following 5 items were included in this second scale: I1, I2, I3, H2, H3 and have a bearing on external change forces, change strategy, and imposed personal demands.

The two obtained scales were negatively correlated $(r=-0,286)$

Comparisons between samples based on independent t-tests By using independent t-tests, the inertia scores of the South African and Australian samples were contrasted. There were overall significant differences in the mean organisational inertia scores between the South African and the Australian samples (see Table 3).

TABLE 3

Comparison between South African and Australian SAMPLES (INDEPENDENT T-TEST)

\begin{tabular}{llllll}
\hline COUNTRY & N & MEAN & SD & & \\
SA & 617 & 491,8379 & 87,9454 & 3,5405 & \\
AUS & 340 & 465,3265 & 111,1698 & 6,0290 & \\
& $\mathbf{t}$ & df & P(t) & Mean Dif & SE Diff \\
\hline $\begin{array}{l}\text { Equal S2 } \\
\text { assumed }\end{array}$ & 4,054 & 955 & 0,000 & 26,5115 & 6,5400 \\
$\begin{array}{l}\text { Equal S2 not } \\
\text { assumed }\end{array}$ & 3,792 & 675,470 & 0,000 & 26,5115 & 6,9918 \\
\hline
\end{tabular}

If the samples were compared on the different theoretical dimensions of the organisational inertia scale the following statistically significant differences emerged (see Table 4).

Table 4 shows that the Australian sample experienced less inertia on the transformational dimension - external environment - as opposed to the South African sample who experienced less inertia on a number of transactional dimensions (job/task requirements motivation for change, emotional impact). Readers should please note that some of these differences might be attributed to chance.

In addition there were significant differences between males and females in the total group (see Table 5).

TABLE 5

COMPARISON BETWEEN MALE AND FEMALES IN THE SAMPLES (INDEPENDENT T-TESTS)

\begin{tabular}{llllll}
\hline COUNTRY & N & MEAN & SD & & \\
\hline Females & 646 & 489,1466 & 96,2270 & 3,7802 & \\
Males & 307 & 468,4072 & 99,2898 & 5,6668 & \\
& $\mathbf{t}$ & df & P(t) & Mean Dif & SE Diff \\
\hline $\begin{array}{l}\text { Equal S2 } \\
\text { assumed }\end{array}$ & 3,079 & 953 & 0,002 & 20,7394 & 6,7360 \\
$\begin{array}{l}\text { Equal S2 not } \\
\text { assumed }\end{array}$ & 3,045 & 584,213 & 0,002 & 20,7394 & 6,8119 \\
\hline
\end{tabular}

TABLE 4

COMPARISON BETWEEN RSA AND AUSTRALIA SAMPLES ON INERTIA DIMENSIONS

\begin{tabular}{|c|c|c|c|c|c|c|c|c|c|c|}
\hline \multirow[t]{2}{*}{ DIMENSION } & \multicolumn{2}{|c|}{$\mathbf{N}$} & \multicolumn{2}{|c|}{ MEAN } & \multicolumn{2}{|c|}{$\mathrm{t}$} & \multicolumn{2}{|c|}{ df } & \multicolumn{2}{|c|}{$\mathbf{P}(\mathbf{t})$} \\
\hline & SA & AUS & SA & AUS & $\mathrm{EVA}^{*}$ & EVNA\# & EVA & EVNA & EVA & EVNA \\
\hline External environment & 688 & 258 & 4,9352 & 5,1611 & $-2,670$ & $-2,885$ & 944 & 543,664 & 0,008 & 0,004 \\
\hline Job task requirement & 688 & 258 & 4,5572 & 4,3101 & 3,498 & 3,545 & 944 & 474,185 & 0,000 & 0,000 \\
\hline Motivation for change & 688 & 258 & 4,6979 & 4,0963 & 6,124 & 5,929 & 944 & 434,164 & 0,000 & 0,000 \\
\hline Emotional impact & 688 & 258 & 4,0559 & 3,8049 & 2,840 & 2,807 & 944 & 451,277 & 0,005 & 0,005 \\
\hline
\end{tabular}

* EVA - EQUAL VARIANCES ASSUMED

\# EVNA - EQUAL VARIANCES NOT ASSUMED 


\section{DISCUSSION}

Two factors were again extracted for this combined sample of South African and Australian managers, in comparison to results in the previous studies (Kinnear \& Roodt, 1998a; Kinnear \& Roodt, 1998b; Roodt, et al., 2001). This again confirms the theoretical dimensions obtained in the separate samples. It appears that the OIS can be used successfully in both South Africa and Australia and this can probably be ascribed to a similar or shared "western" business culture in South Africa and Australia. This supports some comments made by Mangaliso and Nkomo (2001) as well as Mangaliso (2001) regarding the incorporation of local or indigenous worldviews as well as western management concepts in countries.

However, the results indicate that the South African sample's overall OIS scores are significantly higher that those of the Australian sample. The indications are that the South African group is exhibiting significantly less inertia than the Australian sample. This also applies to the transactional dimensions of the model, but not on the transformational dimension of the model. This result may be linked to the vast societal and political changes in South African society before and after the 1994 democratic election and skills gained in managing change programs. It may be postulated that South African organisations were obliged to actively institute change programs so that change leadership, work-unit climate, change related systems, individual needs and values applicable to change were affected in a positive way (cf Mangaliso \& Nkomo, 2001). Such positive transformation efforts in companies seem to have assisted this sample to adequately cope with psycho-social dynamics during change phases. Australians on the other hand seem to be more comfortable with translating external forces for change into change initiatives. There are however a large number of dimensions where no significant differences were obtained.

Another unexpected result was the significant difference between males and females in the sample. The female respondents in the sample in general seem to exhibit more inertia or resistance to change that the male sample. This is contrary to postulations about female managers' career patterns and reactions in organisations (Adler \& Izraeli, 1994) and specifically about female expatriate managers' expectations operating in different cultures (Adler, 1997). This finding needs to be explored in future research and could be probed by gathering more qualitative data collected during in-depth interviews.

\section{REFERENCES}

Adler, N. (1997). International Dimensions of Organisational Behavior. Wadsworth Publishing Company: Belmont, California.

Adler, N. J. \& Izraeli, D. N. (1994). Competitive Frontiers: Women Managers in a Global Economy. Blackwell Publishers, Cambridge.

Behling, O. \& McFillen, J.M. (1997). Translating questionnaires: personal experiences and general conclusions. Proceedings of the Pan Pacific Conference XIV, Kuala Lumpur Malaysia, 3-5 June, pp. 10-12.

Blount, F., Joss, B. \& Mair, D. (1999). Managing in Australia. Lansdowne, Sydney.
Booysen, L. (1999). Male and female managers: Gender influences on South African managers in retail banking. South African Journal of Labour Relations, 23 (2-3), pp. 25-54.

Booysen, L. (2001). The duality in South African leadership: Afro-centric or Eurocentric. South African Journal of Labour Relations, 25 (3-4), pp. 36-64.

Burke, W.W. (1992). Organisation development (2 ${ }^{\text {nd }}$ Ed.) New York: Addison-Wesley.

Connor, P.E. \& Lake, L.K. (1988). Managing organization change. New York: Addison-Wesley.

Du Babcock, B. \& Babcock, R.D. (1997). An analysis of patterns of communication function in multinational corporations: an expatriate perspective. Proceedings of the Pan Pacific Conference XIV, Kuala Lumpur, 3-5 June, pp. 1-3.

Erwee, R., Lynch, B., Millett, B., Smith, D. \& Roodt, G. (2001). Cross-cultural equivalence of the Organisational Culture Survey in Australia. Journal of Industrial Psychology, 27 (3), pp. 7-12.

Erwee, R. \& Pantke, F.T. (1997). The impact of structured interventions on organisational performance. Presented as a poster and abstract in the Best Paper and Abstract Proceedings of the Australian Industrial and Organisational Psychology $2^{\text {nd }}$ biennial Conference, Melbourne June 29: 74.

Hofstede, G. (1993). Cultural constraints in management theories. Academy of Management Executive. 7 (1), pp. 81-94.

Kaiser, H.F. (1961). A note on Guttman's lower bound for the number of common factors. British Journal of Statistical Psychology, 14 (1), p. 1.

Kinnear, C. \& Roodt, G. (1998a). The development of an instrument for measuring organisational inertia. Journal of Industrial Psychology, 24 (2), pp. 44-54.

Kinnear, C. \& Roodt, G. (1998b). The development of an integrative model for assessing organisational inertia. Proceedings of the Pan-Pacific Conference XV, Seoul June 1-3, pp. 142-144.

Kruger, T \& Roodt, G. (2002). Measuring Hofstede's cultural dimensions: Are they reliable and valid? Proceedings of the Pan-Pacific Conference XIX, 29-31 May, Bangkok, Thailand.

Marchese, M.C. (2001). Matching management practices to national cultures in Mexico, Poland and the U.S. Academy of Management Executive, 15 (2), pp. 130-132.

Mangaliso, M.P. \& Nkomo, S. (2001). Eskom's Chairman Rueel Khoza on the transformation of South African business. Academy of Management Executive, 15 (3), pp. 8-15.

Mangaliso, M.P. (2001). Building competitive advantage from ubuntu: Management lessons from South Africa. Academy of Management Executive, 15 (3), pp. 23-34.

Patrickson, M. \& O'Brien, P. (2001). Managing Diversity - an Asian and Pacific focus. John Wiley and Sons Australia, Milton, QLD.

Pettigrew, A.M. Woodman, R.W. \& Cameron, K. (2001). Studying Organisational Change and Development: challenges for future research. Academy of Management Journal, 49 (4), pp. 697-713.

Roodt, G., Kinnear, C., Erwee, R., Smith, D., Lynch, B. \& Millett, B. (2001). Measurement of organisational inertia: portability of a South African scale in an Australian context. Journal of Industrial Psychology, 27 (2), pp. 57-61.

Schepers, J.M. (1992). Toetskonstruksie: Teorie en Praktyk. Johannesburg: Rand Afrikaans University publishers.

Trompenaars, F. (1993). Riding the Waves of Culture. London, The Economist Books. 